\title{
Alien invasions: the British Musicians' Union and foreign musicians
}

\author{
MARTIN CLOONAN and MATT BRENNAN \\ Music, School of Culture and Creative Arts, University of Glasgow, 14 University Gardens, Glasgow G12 8QH \\ E-mail:martin.cloonan@glasgow.ac.uk \\ Reid School of Music, University of Edinburgh, Alison House, 12 Nicolson Square, Edinburgh EH8 9DF \\ E-mail:m.t.brennan@ed.ac.uk
}

\begin{abstract}
This article examines the policies of the British Musicians' Union towards the employment of musicians who were not UK citizens in the period from the 1920s to the 1950s, with particular emphasis on an alleged ban on American musicians entering the country. Drawing on a number of hitherto largely ignored and/or unavailable sources, it argues that many previous accounts of these policies have simplified a more complex picture. We illustrate that complexity and suggest that the issues surrounding the ban are ones which continue to resonate.
\end{abstract}

\section{Introduction}

In May 2009 the UK's Migration Advisory Committee asked the government to exempt contemporary dancers and orchestral musicians from a new points-based visa system which it was planning to implement. The net effect of this implementation would have been to make it harder for such artists to enter the UK on work permits. The UK's Musicians' Union (hereafter MU) responded to this by noting that, while it was not opposed to foreign musicians working in the UK under certain conditions, 'we do not agree with [...] the inclusion of orchestral musicians in the recommended shortage occupation lists, because we have yet to be convinced of there being a shortage of orchestral musicians in this country' (Smith 2009).

This reaction was part of a much longer story in which the MU has sought to limit the number of foreign musicians entering the UK to work, on the basis that such entrants deny work to British musicians who could, the MU argued, equally well perform the necessary musical tasks. Since the late 19th century, the MU has played a vital, yet largely unexplored, role in shaping musical life in Britain by negotiating the relationship between professional musicians and the institutions within which they work. As we will show, such negotiations were particularly sharply felt in the history of British jazz before 1955 and any serious account of that history has to reckon with the MU's controversial policies towards foreign musicians during this era. These have previously been frequently misunderstood. However, there is now an opportunity to shed new light thanks to an important new archival resource in 
the form of the MU Archive. This has collected an unprecedented amount of pertinent documents under one roof, allowing for new research which can take significant steps towards improving the understanding of the MU's motivations and its impact.

This article examines the union's policies towards the employment of non-UK citizens in the period from the 1920s to the 1950s. We hope to present a more nuanced account of these policies than has been previously available, and to clarify some of the concerns behind key decisions made by the MU during this time. This will entail outlining the MU's origins with particular emphasis on contextualising the development of its policies towards 'alien' musicians and its relations with the Ministry of Labour. We will then draw on evidence from both MU and Ministry archives to outline the key developments in the treatment of foreign musicians and offer a new perspective on the MU's role in this.

Such contextualisation is necessary to highlight the problems which the MU was facing and which informed its actions. In addition, we will clarify the extent of the restrictions and the length of time for which they operated. We outline the key role that individuals within the MU were able to play and suggest that, while the overall policy could not be regarded as racist, it sometimes acted a vehicle for the expression of such sentiments. We show that while restrictions on US musicians have previously been the ones most highlighted, they were part of a broader attempt to restrict the entry of all 'alien' musicians. We consider the longer term impact of the restrictions, arguing that while some of the motivations behind them may be understandable, their easing coincided with more employment opportunities for UK musicians in the international market.

It should be noted here that most previous mentions of the restrictions placed on the entry of alien musicians into the UK appear within larger, mainly jazz-centred histories which tend to deal with the issue only in passing. Importantly, there is a high degree of inconsistency between them regarding the terms, length and scope of these restrictions. Many histories dealing with jazz in Britain cite a ban on American dance bands between roughly the mid-1930s and the mid-1950s, but there is a lack of consensus about its start and end dates and on whether it formally constituted a ban. ${ }^{1}$ There is also confusion about whether the restrictions applied to American musicians exclusively or to all foreign nationals, and on whether it applied specifically to dance bands or across all genres. Part of the problem with separating the facts from the myths has been a lack of access to primary sources from within the union. Here our initial archival research has revealed that the word 'ban' was never actually used in MU documents from this era. There was, however, much discussion of barring foreign musicians unless reciprocal musician exchanges could be arranged with the unions in the foreign performers' country of origin. In addition, as we shall see, some MU officials flirted with xenophobic and even racist sentiments during their attempts to deny entry to foreign musicians.

Further muddying the waters is the fact that a distinction has to be made between the MU's ability to exert control over 'musicians' - as opposed to 'singers' or 'entertainers' - as the latter two were represented by different unions, such as the Variety Artistes' Federation (VAF). Thus, canny promoters would describe some acts as variety rather than as musical per se. For example, in 1937 the MU complained that the VAF - which primarily represented music hall artists and singers rather than instrumental musicians - had allowed some entertainers to work in the UK as variety acts, even though part of their act included instrumental musical performance (Musicians Union Report, September 1937, p. 2). Throughout this era, individual 
performers, occasionally including bandleaders, were able to circumvent the restrictions and play - generally with UK musicians replacing their usual band. ${ }^{2}$ What remains certain, however, is that for many years 'alien' musicians were denied work permits in the UK as a result of action taken by the Ministry under pressure from the MU. We suggest that these events are best understood by exploring the roots and context in which the MU and its attitudes towards foreign workers were formed.

\section{The development of the MU and relations with the Ministry}

The MU has contributed to the UK's musical life for over 100 years, but has remained largely ignored by historians. The only existent MU history is an official booklet released to mark the union's centenary anniversary (Jempson 1993). This traces the MU's origins to a meeting held in Manchester in November 1893, which was prompted by a letter sent to orchestral musicians by 21-year-old clarinettist Joe Williams. The meeting led to the formation of the Amalgamated Musicians' Union (AMU) which from its inception was concerned with the problem of 'alien' musicians working in the UK. Thus Williams sought 'to reduce competition, particularly from European musicians who had almost unrestricted access to work in Britain', and in 1901 the Union petitioned King Edward VII to prevent 'the wholesale importation of foreign bands' (Jempson 1993, p. 8).

In 1921 the AMU merged with the London Orchestral Union of Professional Musicians to form the MU. By this point the issue of foreign workers was high on many agendas. From the 1870s onwards, successive governments came under pressure to restrict immigration as Britain faced economic and political competition (Holmes 1991). The Trades Union Congress was at the forefront of calls to restrict immigration (Winder 2004, p. 197). The first legislation limiting foreign immigration in the UK was the 1905 Aliens Act which established an immigration control bureaucracy with powers of exclusion and enabled courts to recommend 'undesirable aliens' for deportation (Cessarani 1996, p. 62). Henceforth 'entry for aliens became a discretionary rather than an absolute right' (Holmes 1991, p. 21).

World War I clearly provoked xenophobia amongst musicians just as it did in other professions in Britain. A contemporaneous excerpt from the Musical News suggested that the war:

Has suddenly brought to a head the long-smouldering resentment against foreign dominance in British musical circles ... [now is] is the chance for the native to assert his proper pre-dominance in the land of his birth ... After having their employment prejudicially affected for years past by Germans and Austrians, [orchestral musicians] may be excused if they fail to see how the substitution of French and Belgians is likely to benefit their condition. (Quoted in Fifield 2005, p. 97)

In 1914, an Aliens Restrictions Act was introduced as a wartime measure aimed at nationals of enemy countries and 'obliged [foreign nationals] to register with the police' (Cessarani 1996, p. 62). While subject to periodic review, these measures were retained and extended after World War I ended (Dummett and Nicol 1990, p. 108). Thus the AMU was cutting its teeth at a time when suspicion of foreigners was gaining official sanction. It was soon to turn to officialdom for help in denying foreign musicians entry to the UK. 
The Ministry of Labour was established by the New Ministries and Secretaries Act of $1916^{3}$ and in 1920 a new Aliens Order required all employers who wished to import foreign labour to obtain its permission. The Ministry was soon lobbied by the AMU which, for example, protested at the importation of foreign musicians in May 1920 (National Archives LAB 2 1187/EDAR3011/1922/AMENDED). The MU came to view the Ministry as a means of enforcing restrictions on 'alien' musicians wishing to enter the UK and the relationship between the union and the Ministry came to be a key determinant of the fate of such musicians.

Meanwhile the growing popularity of American jazz, dance and pop styles among British audiences led to demands for appearances by American star performers. This caused consternation in the MU which saw the importation of any 'alien' musicians as denying work for its own British members. It continually lobbied the Ministry to deny work permits to any applicant. Sentiments against the employment of foreign musicians intensified as economic times worsened and more MU members became unemployed. ${ }^{4}$ In March 1923 the MU met the Conservative government's Minister for Labour, Sir Montague Barlow, and pressed its case for denying aliens entry to the UK. Concern about a proposed tour by Paul Whiteman in 1923 was such that it was able to take place 'only through the direct intervention by the Prince of Wales' (Parsonage 2005, p. 181), and on condition that an equal number of British musicians were employed at the gigs. This stipulation was subsequently referred to by the Ministry as 'the Whiteman clause' (LAB 2 1187/13). Moore (2006b) reports that hereafter a policy was adopted whereby:

1. Work permits would normally be issued for eight weeks only;

2. Any American band at a particular venue had to return home before they could be replaced by another American band there;

3. Where an American band was employed in a ballroom or nightclub, an English band had also to be employed;

4. Where any American musicians were to be employed in an otherwise English band, there should be an equal number of British players. ${ }^{5}$

Getting work permits was a painstaking process and one which not all foreign musicians (or British concert promoters) were willing to go through. The American bandleader and agent Paul Specht first visited the UK in 1923 and attempted to return by ship in July 1924 with a band of 'students', only to be refused entry at Southampton. Following an intervention by the US Secretary of State, Charles Hughes (whom Specht's band had entertained during the trip across the Atlantic), the band were admitted and, following further pressure, given work permits (Moore 2006a).

Across the Atlantic the MU's equivalent was the American Federation of Musicians (AFM), which had adopted an 'unswerving policy of opposing any application by English or other foreign bands to work in America' (Moore 2006b), meeting such applications with threats of strike action. Via this method the AFM was able to veto any proposed visit by UK musicians and any alien musicians granted entry had to wait 6 months before they could apply for AFM membership and seek gigs (Moore 2006a; LAB 2/1188/EDAR528/2/1929). One result of the AFM's threats was that while around 50 US bands visited the UK during the 1920s, no British band went the other way (Moore 2006a).

In early 1925, London's exclusive Kit Kat Club applied to the Ministry for permits for a series of residences by US bands. The MU responded by writing 'a lengthy letter of protest' (Moore 2006a). In a significant move, the Ministry judged that these 
acts offered a kind of musical entertainment which British musicians could not offer a point which it appears MU officials initially conceded (Moore 2006b). However, as will be shown, such distinctions between UK and US musicians' musical prowess were to become one of the key areas of disagreement between the MU and the Ministry. Further ructions between the two were caused by the fact that henceforth the MU 'seems only rarely to have been consulted on Work Permit applications' (Moore 2006a).

In August 1925 the agent Harry Foster wrote to the Ministry complaining that agents could not operate unless they knew that American musicians would be granted permits. He was seeking to import US musicians into the Kit Kat Club and argued that they were 'highly specialised', implicitly suggesting that no British musician could replicate their work. Foster also noted the Ministry stipulation that for every American imported a British musician must also be employed, but argued that 'English dance bands are ... no attraction'. However, he also acknowledged that the clause did have the effect of creating work for British musicians (LAB 2/1188/AR3434/1930).

In February 1929 the Minister of Labour, Sir Arthur Steel-Maitland (Conservative), explained the prevailing permit system to Parliament:

If the employer desires to bring in a complete band to play for dancing, he is required to engage, or to continue to engage, a British band equal in size to the alien band. If it is proposed to augment a British dance band by the introduction of alien musicians of outstanding ability, such introduction may be permitted up to about 25 per cent, on condition that no British player is discharged to make room for the aliens. Complete bands to play symphony or national music ... are admitted on an assurance that no British band or British player is being displaced, and that the alien band will not play for dancing. No condition other than a limitation of the period of stay in this country is in general imposed in the case of concert instrumentalists and persons giving stage performances at music halls (Hansard, 11 February 1929; our emphasis).

This system effectively remained in place until the mid-1930s. Meanwhile the increasingly beleaguered MU faced another pressing issue - technological change. The arrival of the 'talkies' into cinemas and the subsequent displacement of cinema orchestras had a devastating effect on musicians' employment. While this has been most clearly documented in the USA (Mermey 1929; Hubbard 1985; Kraft 1994a, b), it also caused major problems in the UK. On 20 June 1929, the MU's Birmingham branch wrote to the Minister about 'the abnormal amount of unemployment among British musicians created through the introduction of mechanical music', and on 4 July the Bristol branch called for the Ministry to investigate 'the menace confronting musicians by the introduction of sound films and mechanical music' (LAB 2/1188/EDAR528/2/1929). MPs asked questions in Parliament ${ }^{6}$ and the London Trades Council told the Ministry that it was wrong to import American musicians at a time when 'American capitalists' were causing unemployment amongst British cinema musicians (LAB 2/1188/EDAR528/2/1929). ${ }^{7}$

Adding to their woes, the MU's members also faced continual competition from within their own national borders, in the form of military and police bands, who would play for lower than agreed MU rates or even for free. With the economic downturn of the 1930s, the arrival of the talkies and competition from British military and police bands, something of a siege mentality seemingly developed within the union. But it had at least some support in its attempts to deny foreign musicians 
entry to the UK. During one meeting with the Ministry, Captain Humphries, Entertainment Manager of London's Café de Paris in London, supported a temporary ban on alien musicians in order to see if UK musicians could be given time to match them (LAB 2/1188/EDAR528/2/1929). By now Melody Maker was also full of letters complaining that foreign musicians would take over live popular music completely unless something was done (Schwartz 2007, p. 8). However, many concert promoters - not to mention audiences and some musicians - wanted the chance to bring American star performers over to the UK, and promoters therefore continued to argue the case for 'outstanding' and/or specialist musicians to be allowed entry.

There remained some common ground between the Ministry and the Union as both were concerned about overseas work opportunities for UK musicians. Here a key sticking point was the AFM's continual refusal to approve proposed American tours by such musicians. In August 1924 the MU, Ministry and TUC discussed the restrictions placed on UK musicians trying to tour in the USA. The TUC's Ben Tillett noted that while US musicians were playing in the UK, the USA was placing restrictions on British musicians going to play there (MU London Meeting Agenda, 16 September 1924). In June 1929 the Birmingham branch of the MU complained to the new Minister, Margaret Bondfield (Labour), that 'British bands are barred in America' (LAB 2/1188/EDAR/2/1929) focusing on the bandleader Jack Hylton whose proposed 1927 US tour was cancelled in the face of an AFM strike threat. When he was offered another tour in July 1929, Hylton's accountant, R. Aspen, wrote to the Ministry, noting that:

all the Managements in the States who are going to play Mr Hylton and his band were informed by the American Musical Federation (sic) ... that if they played him ... the musicians would blacklist their respective managements for ever. (ibid)

Aspen's letter also proposed the idea of the reciprocal exchange of musicians, asking the Minister 'to endeavour to make the American Officials open their doors to us when you are granting permits to Foreign Bands' (ibid). In the same month, the MU, London Trades Council and the National Association of Theatrical Employers met with Bondfield to discuss work permits for 'aliens'. Bondfield argued that entertainment was an international business requiring international employment and - in a variant of previous arguments about outstanding ability - claimed that any musicians admitted to the UK were 'highly specialised' so that 'it is doubtful whether they can be regarded as direct competition with British musicians' (ibid). In a statement to Parliament on 31 October, Bondfield announced that while previously the Ministry had tended to consult the MU on foreign work permits only 'in cases of doubt or difficulty', it had arranged that henceforth 'they should be informed of all applications for permits' (Hansard, 31 October 1929; our emphasis).

Bondfield also noted that her Department 'limits the entry of foreign musicians to the fullest extent which is justifiable' (Hansard, 31 October 1929). However, tensions between the Ministry and the MU continued, with Bondfield telling the TUC in December of her annoyance that the MU opposed every application 'regardless of its merits' (LAB 2/1188/EDAR/2/1929). In January 1930 the MU again wrote to the Ministry, this time expressing concern that (i) it was being ignored by a Labour government, (ii) military bands were offering competition to its members, and (iii) so were alien musicians (LAB 2/1188/EDAR528/2/1929). An article by MU official W.B. Batten on 'The Invasion of Alien Musicians' was included in the 
correspondence. Meanwhile Bondfield's civil servants advised her that meeting with the Union was 'a complete farce' as their policy was to oppose every application (ibid).

In July Bondfield assured Parliament that only a 'very small number of permits (are) given' and that one consideration was the possible reciprocal effect on British musicians seeking foreign engagements (Hansard, 24 July 1930). Permits to musicians were issued only 'if they are of unusual merit or possess some special feature which cannot easily be reproduced in this country' and even then only 'in very exceptional circumstances' (Hansard, 24 July 1930). The exceptional skills which imported musicians were expected to have were reiterated by Bondfield in a letter to the London Trades Council where she additionally noted that only six 'alien' bands were currently in the UK (LAB 2/1188/EDAR528/2/1929). The MU, on the other hand, claimed that despite Bondfield's assertion that it was 'invariably consulted', such consultation only happened once contracts had been put in place which it would have been very hard to break (LAB 2/1188/EDAR528/2/1929). Another problem for the MU was that permit extensions were the responsibility not of the Ministry of Labour, but of the Home Office whose only concern was whether the individual concerned had behaved themselves while in the UK - not their impact on domestic employment.

The MU was also under attack for not actually having many dance musicians amongst its membership. In 1925 Foster wrote to the Ministry claiming that the VAF, which was not against aliens performing in the UK, represented more dance musicians (AR 278/41/1925), a claim which the MU refuted in a letter to the Minister in September 1930 (LAB 2/1188/EDAR528/2/1929). In the same month the MU formed a Dance Band Section, following a meeting in August at the Union's Victory House which attracted 500 dance musicians including Hylton and another bandleader, Jack Payne. Together they became the Dance Band Section's leaders (Jempson 1993, p. 16). The new Section was seemingly formed in order to legitimate the MU's claim to represent dance musicians - and to further the fight against 'alien' entry. It wanted any employer thinking of hiring a foreign musician to first contact it to see if suitable British musicians were available (Minute, 2 November 1930).

The issue of foreign musicians performing in the UK came to an unprecedented level of public awareness in June 1933, when Duke Ellington arrived in the UK for a British tour. Hylton publicly supported Ellington's right to perform, but the British press made much of the fact that Hylton himself had been denied a work permit to tour the US. This tangible lack of reciprocity further fuelled the debate and when a further British tour by Ellington was proposed in 1934, Hylton opposed it. The Ministry was now torn between MU intransigence on the one hand - as it routinely opposed all applications - and a concern on the other that AFM stipulations were harming British musicians. An announcement from the US Labor Department - which had previously considered work permit applications from UK musicians, only to have any proposed acceptance effectively vetoed by AFM threats of strike action - that it would no longer even consider applications (Moore 2006b) appears to have been the final straw for the Ministry. In January 1935, as hopes for movement by the AFM receded, the Ministry opposed a further application by Ellington and announced that it would oppose any similar applications. Parsonage (2005, p. 255) writes that:

A Press Communiqué was issued on 29 March 1935, stating that: 'the Minister does not feel able to grant permits freely to American bands to take engagements of the Variety Hall 
type. He will, however, be glad to revert to his former policy as soon as he can be assured that no less favourable treatment will be accorded to British Bands seeking engagements in the USA'.

This is a key moment in the history of British policies towards tours by 'alien' musicians as it clearly marks the start of a particular embargo on the entry of American musicians. However, it is also here that previous accounts of both MU and government policy often appear muddled - particularly about the scope and length of the restrictions. Fortunately, new sources have become available from the MU archive (which we have supplemented with additional research at the UK's National Archives), and these shed light on the MU's motives and internal decision making concerning restrictions on foreign musicians. We will now revisit the build up to, and execution of, these restrictions from the 1920s up to World War II, via this new archival material.

\section{An archival perspective on the $\mathrm{MU}$ in the interwar years}

The MU's Archive at the University of Stirling 8 and the UK's National Archives which house Ministry of Labour records - provide further details of how the union responded to the 'alien' threat and on the nature of the restrictions which were imposed on foreign musicians. What follows is an initial attempt to trace the development of the prevention of performances by foreign musicians from within the archives. Here we draw upon Minutes of the MU's London General Meeting (1921-1936), the Dance Band Committee (1930-1931), the Musicians' Union Report (1934-1949), its replacement The Musician (1950-1959), reports to delegate conferences (1943-1997) and files in the National Archives.

The first finding that our archival research yields is the prominent role played by the aforementioned W.B. Batten, who led the charge in the MU's opposition to foreign musicians for most of the interwar period. His role reveals that prominent individuals within the MU had the capacity to influence the fate of foreign musicians who wished to enter the UK. As we shall see, it also reveals that denial of entry into the UK was not always underpinned by the highest of motives. Batten trained as a professional cornet player, but soon was also a key member of the MU in his role as joint secretary of the London Branch. From at least 1922 to 1940 (when he was injured by a bomb attack at a London cinema), Batten attended, as one MU report described it, 'to that part of Union activities which safeguards the interests of our members from the competition of alien musicians. On many occasions British musicians have secured engagements that would have been performed by foreigners had representations not been made to the Ministry of Labour' (Musicians Union Report, October 1934, p. 2). Elsewhere Batten is referred to as the MU representative 'who for many years has acted for the Union in regard to all questions relating to aliens' (Musicians Union Report, August 1937, p. 2). In his own article entitled 'Alien Bands', Batten proclaimed that 'The Musicians' Union has never ceased doing everything in its power to prevent (or failing that, restrict) the entry of the alien musicians into this country' (Musicians Union Report, July 1935, p. 6).

Batten clearly had significant influence with government officials. In 1922 he reported on a forthcoming meeting with the Home Office about the issue of foreign musicians and assured members that 'everything possible' was being done to restrict the importation of American jazz musicians (London Meeting Minutes, 4 October 
1922). He later informed the Ministry that 'any attempt to import players which will interfere with our members' interests will be bitterly resented' (London Meeting Agenda, 22 February 1924). Perhaps mindful of the need to keep employers on board, Batten blamed greedy agents - rather than promoters - for the alien influx (AR278/41/1925-A19 1926).

Batten also wrote to the Ministry complaining about the Kit Kat Club employing American musicians and argued that the restrictions on employing aliens had 'enabled British musicians to build up and develop native talent to such an extent that only a few very special American musicians are in any way superior to ours' (AR278/41/1925-A19 1926). It is clear that Batten believed that given sufficient time British musicians could match any 'alien'. Thus in 1935 he suggested that 'the Union's opposition to the individual alien musicians is now becoming more effective owing to the development in this country of a type of musician more closely approximating to the star alien performer' (Musicians Union Report, July 1935, p. 6). While this seemingly undermined the MU's earlier stance that UK musicians had always been equal to any 'alien' musician, Batten lauded in particular the rise of the British bandleader Geraldo, whose 'success has helped tremendously in arguments with the Ministry of Labour in showing that material is already in the country to produce practically anything that can be brought from the continent' (Musicians Union Report, July 1935, p. 6).

When the Dance Band Section formed in 1930, it was chaired by bandleader Jack Payne but seemingly led in practice by its secretary - Batten. On 19 September 1930 the minutes of its second meeting discussed the 'Eligibility of Aliens' for membership in the context of a letter from the Ministry concerning permit applications by two American musicians already resident in the country. Here 'it was generally agreed that the Dance Section Committee should not accept such persons as members unless they first obtain letters of British citizenship'. (In the longer term, despite some inconsistency as to the criteria for their acceptance, some alien musicians resident in the UK did become MU members; Musicians Union Report, October 1935, p. 1.)

Throughout 1930 and 1931, Batten used the Dance Band Section as a vehicle to promote the MU's stance against foreign musicians. Whether it was a request by the Savoy Hotel requesting to employ an accordion player for a tango band (24 October 1930), the Trafalgar Restaurant wishing to import an Italian band (21 November 1930), or even Jack Hylton himself requesting to temporarily employ foreign musicians in his touring band (7 November 1930, 14 February 1931), the meeting minutes show that requests were met with either outright opposition or insistence that any alien musician be replaced by a British player 'as soon as it could be conveniently arranged' (7 November 1930).

Batten also arranged meetings with bandleaders and employers who had not yet made such requests in order to educate them on the MU's position on alien musicians. He reported in one meeting that bandleaders responded by expressing 'hearty commitment' to the union and requesting membership application forms (Minute, 17 October 1930). And in a meeting between MU officials, the Ministry, the London Trades Council and representatives of London venues Batten noted that employers had been convinced that 'before any permit for the introduction of an alien is applied, the employer should meet the Union officials to discuss available British material and further that the necessity for the introduction of complete alien bands had largely passed away' (7 November 1930). (The Ministry's account of this meeting 
is somewhat different, stating that Batten admitted that there may previously have been some justification for allowing American musicians entry on the basis of special ability, albeit while maintaining that British musicians could now do the job; LAB 3/1188/EDAR/2/1929).

The last meeting of the Dance Band Committee was held in February 1931, and no further meetings were held. However, Batten also had other opportunities to oppose visits by 'alien' musicians, including in print. Here archival research sadly reveals that Batten's zeal in opposing work permits for foreign musicians was sometimes tainted by racist and anti-Semitic overtones, as demonstrated by the following article which he authored:

At Ciro's Club, just prior to starting an engagement in September, two coloured sax players, forming part of a combination that was to start an engagement there, were reported to the police as being in this country without Labour permits. The two men concerned appeared at Marlborough Street Police Court, were remanded, and, on appearing the following week, were sentenced to be deported and barred from returning to this country for three years. The coloured band, through the loss of these two men, was unable to start the engagement, and a white band was engaged, and was followed by another white band a few weeks later, which combination is still playing at Ciro's Club. (Musicians Union Report, January 1934, p. 4)

In the same article Batten details his efforts to deny work to a Jewish refugee cellist from Germany (formerly exiled from Russia), who was 'discovered rehearsing at the Prince Edward Theatre':

I complained to the Ministry ... and found that he had a special permit from the Home Office ... The Ministry took immediate action on my complaint and he finished at the Prince Edward Theatre. He then made application to join the Union but the Committee could not accept him [... On November 10th, the alien's solicitor] called to see me in order to plead his case. I explained the attitude of the Union thoroughly; impressing on him our first duty was to our own unemployed, and that while there were disengaged cellists in this country the Union could not possibly agree to his client obtaining employment here. At the conclusion of the interview the solicitor admitted that although he was disappointed, our case was too strong to argue against... I am now informed by one of our of members that the Jewish Refugee Committee has sent, or is about to send, the Russian and his family to South America. (Musicians Union Report, January 1934, p. 4)

Batten's specific reference to the ethnicity and religion of the foreign musicians (and that the replacements for the 'coloured band' at Ciro's Club were white) suggest that he viewed such details to be significant. This raises some unsettling questions about whether Batten's motivations (and by implication those of the organisation he represented) came solely from a desire to protect MU members.

The examples above also lead us to the second key finding from our archival research, which is that MU restrictions on foreign musicians were clearly not limited to American dance bands, but were applied across all genres of music and all nations including continental Europe. The archives reveal that while the popularity of jazz meant that US dance musicians were at the forefront of the MU's mind, all foreign nationals caused concern (Musicians Union Report, July 1935, p. 6).

It is clear that from the 1920s onward, for instance, the MU tried to oppose not only foreign jazz performers but also foreign classical orchestras. In 1923 it successfully prevented a planned visit by the Vienna State Orchestra which was to accompany the Vienna State Opera. A successful campaign for British musicians to be 
used instead was hailed as 'a great victory for the Union' (London Branch Agenda, 22 February 1924). A letter from Joint Secretary Fort Greenwood to the Austrian authorities noted that 'we have consistently opposed the introduction of foreign orchestras into British theatres since our formation over 30 years ago: in fact, the inception of the London movement was largely due to the attempt to permanently install at Covent Garden a German orchestra for the "Grand" seasons of opera' which was successfully opposed (London Branch Agenda, 22 February 1924). The union argued that its 'uncompromising attitude' was the key to its success (London Branch Agenda, 22 February 1924). Such being the case, it sought to avoid any compromise, proclaiming that 'members can rest assured that we shall take all possible steps to prevent any further influx of these competitors' (London Branch Agenda, 18 May 1923).

Further evidence of opposition to visits by any foreign musicians comes from the Minutes of the London General Meeting, the first of which came in August 1921, just after the Union had formed. A sample of the topics discussed at early meetings gives a flavour of its concerns: competition from military bands (August 1921); a dispute about a Russian ballet appearing at the Alhambra Theatre (October 1921); and 'US Jazz Bands' (October 1921). The agenda for the 18 May 1923 meeting included an article headed 'American and Other Alien Musicians' which stated that 'we are now threatened with an American invasion. There being a demand for "jazz", frantic efforts to import American musicians are being made by a number of employers and agents with the usual disregard for the claims of British musicians'. The advent of prohibition in the US was viewed as meaning more American musicians would attempt entry into the UK for work, but members were warned that: 'In keeping an eye on the Americans, however, we must not ignore the danger from the continental musician, especially those from ex-enemy countries' (ibid). Members were encouraged to report any foreigners working without permits, not just US musicians.

The all-encompassing nature of the MU's approach can also be seen in its attitude to British Commonwealth musicians. Prior to the passing of the Commonwealth Immigration Act in 1962, Commonwealth citizens were free to enter the UK to find work (Clayton 2006, p. 10). In July 1936 it was reported that fears that American musicians were trying to disguise themselves as Canadians in order to gain entry appeared to be unfounded, but that the Ministry 'could not interfere with' the employment of Canadians as they were Commonwealth citizens (London General Meeting Minute, 7 July 1936). The MU's journal responded by alluding to 'the strange anomaly by which foreign and colonial artistes and musicians obtain access to this country' and called for proper legislation to be passed (Musicians Union Report, May 1937, p. 8). The issue returned in May 1938 when a motion was passed forbidding members from playing with English bandleader Ray Noble's Canadian Band. However, the MU's opposition to Commonwealth musicians touring did not prevent it from expressing outrage when its Australian counterpart imposed restrictions on UK musicians becoming members and a feisty exchange of letters followed (Dreyfus 2009, pp. 8-9).

In summary, while previous mentions in scholarship of the MU restrictions on foreign performers have emphasised particular events - particularly Ellington's 1933 UK concert as the last major concert by an American dance band, and the tit-for-tat rejections of work permits from the AFM and MU occurring throughout 1934 leading up to the press communiqué by the Ministry of Labour in 1935 - these need to be contextualised within the more mundane activities of the MU, and should ultimately 
be viewed as part of the MU's longstanding opposition to foreign musicians across all genres and nationalities during this era.

\section{The postwar era and the development of reciprocal exchanges}

World War II brought disruptions to all aspects of British life, including union activity. In 1940 Batten temporarily retired from the MU after being seriously injured while attending a cinema that was bombed. By 1947 he had recovered and had become chairman of the Executive Committee, but henceforth the MU softened its rhetoric around 'alien' musicians, moving from overt attempts to bar them towards the encouragement of reciprocal exchanges. It also began holding biennial delegate conferences which provide the sources for much of what follows. A motion at the MU's first postwar conference urged that the Union pursue every possible opportunity for fraternal relationships with international musicians and pledged support for 'the reciprocal interchange of orchestras, dance bands, and music of the various countries' (Musicians Union Report, April 1945, p. 2). In 1947 the Executive reported a planned visit by the AFM President James Caeser Petrillo to discuss various matters including reciprocal exchanges, but this had to be abandoned when Petrillo was forced to remain in the US to counter planned legislative moves to restrict union activities (Executive Report to Conference 1947, p. 25). The conference also saw a proposal from the Executive for the formation of a World Federation of Musicians to discuss such issues as broadcasting and recording. This was established (as FIM) in 1948.

By the late 1940s reciprocal exchanges between the MU and unions in continental Europe became an increasingly accepted practice (Proceedings 1949, p. 30). Dance bands from European countries could get work permits provided that a similar British band was allowed to perform the same number of concerts in the relevant country. There are several examples of such exchanges at this time, including agreements with France (Proceedings 1949, p. 30) and the Netherlands (Melody Maker, 21 January 1950, p. 1). But the policies were inconsistent, with some countries such as Belgium accusing the Ministry of a 'lack of reciprocity', whereby British musicians were allowed to perform there while Belgian musicians were continually denied UK work permits (Melody Maker, 16 July 1949, p. 1).

Reciprocal exchanges with the US, on the other hand, remained an unresolved issue and the hostility of Anglo-US relationships is exemplified by an attempt by promoter Val Parnell to bring Benny Goodman to perform. In order to circumvent the rules Parnell marketed Goodman's show as a pure variety - as opposed to musical - act, knowing the demand would be nevertheless intense in a country starved of 'authentic' American jazz. A Melody Maker (14 May 1949, p. 1) article captured the tension:

With all Paris flocking to hear the American aces at the Festival, it is indeed ironic that ... there seems more than a likelihood that a sensational project to feature world-famous star Benny Goodman at the London Palladium early in July may be vetoed by edict of our own Musicians' Union. The plan ... is to bring Benny, supported by six top-line American musicians, plus two dancers, two vocalists and a comedian, to open at the Palladium on July 4 for two weeks. The whole Goodman offering would be essentially variety; but the immense interest aroused among British musicians, and the tremendous fillip to the business which a visit from the great American clarinetist-bandleader to Britain would constitute, is almost incalculable.

Mr. Val Parnell told the Melody Maker .. 'I have been urged, both by the members of my own Skyrockets Orchestra and by many other leading musicians here, to bring Benny 
Goodman over, and I know that a visit from him will be regarded by English musicians as an epoch-making event. ... The whole thing is essentially a vaudeville act, and is at present touring the US as such. From these facts - plus the certainty that Goodman would appear nowhere else - it will immediately be obvious that no English musician could possibly be put out of work, or even be affected in any way, by a visit from the Goodman retinue'.

After protracted discussions with the MU, Goodman was finally allowed to perform but without any of his American accompanists. These were replaced by the Palladium's resident orchestra, the Skyrockets (Melody Maker, 18 June 1949, p. 1; 9 July 1949, p. 1).

As with the interwar period, promoters occasionally decided to ignore MU policies and take matters into their own hands. Two famous examples come from 1949, when two promoters, Bert and Stan Wilcox of the London Jazz Club, tried to bring Sidney Bechet to tour. These plans were routinely vetoed by the MU (Melody Maker, 8 October 1949, p. 1). Soon after, another promoter, Bix Curtis of the Willesden Music Makers' Club, faced a similar MU veto when attempting to tour the saxophonist Coleman Hawkins (Melody Maker, 26 November 1949, p. 1). However, in both cases the promoters ignored the rules, with Bechet and Hawkins performing on stage unannounced and causing Melody Maker front page headlines. The report of Bechet's appearance was ecstatic: 'Bechet Plays in London! 1,750 Fans go wild at dramatic appearance of great jazzman at Wilcox Brothers' Concert - The most dramatic and exciting occasion in the history of British jazz for the last 15 years' (Melody Maker, 19 November 1949, p. 1). Similar adulation followed Hawkins' subversive appearance (Melody Maker, 17 December 1949, p. 1). While in each case the promoters were represented as heroes by the press, in 1950 they were summonsed, found guilty and fined for unlawfully aiding and abetting a performer in contravening Article 1 (4) of the Aliens Order, 1920 (Melody Maker, 20 May 1950, p. 1).

In 1950, the MU Executive reported to the Conference that it had considered a resolution requesting a change to the policy of opposing entry of American bands into Britain but had declined to do so (Musician, July-October 1950, pp. 15-16). Following a meeting in November 1950 the Ministry agreed to consult the union at the earliest possible stage when requests for work permits were received. However, it was also noted that the Ministry have ... issued permits on several occasions despite objections made on behalf of the Executive'. Despite this the Union had successfully prevented some individual instrumental performances even after permits were issued and had also 'been successful in limiting very strictly the employment of foreign conductors with visiting theatrical productions' (Executive Committee Report 1951, p. 53). The Conference also heard a motion from the South West District calling for meetings with both the FIM and AFM to discuss easing restrictions (Conference Agenda 1951, p. 30).

In autumn 1952, a Visiting Orchestras Consultative Association (VOCA) was established with the MU as a member. VOCA eventually included the Arts Council, the Association of British Orchestras, agents, local authorities and employers. The Executive explained to the 1953 Conference that the Union was not opposed to foreign musicians playing in the UK, but insisted that 'there should be strict control, and that there should be reciprocity between the two countries and the musicians' organisations involved' (Executive Report 1953, p. 53). It also reported that it had decided not to meet with the AFM to discuss the situation in their countries. A motion for it to do so was lost by 29 votes to 5 (Conference Proceedings 1953, p. 33). 
However, the Executive Report to the 1955 conference noted that the General Secretary had met Petrillo in July 1953, with details of the meeting published in The Musician in April 1954. The conference was told that relations with the AFM 'have continued to be good' (Executive Report 1955, p. 60). The Union's continued representation at VOCA meetings saw it expressing concern that visiting orchestras were contributing to an 'unbalance' (Executive Report 1955, p. 64). Clearly it did not always agree with VOCA's stance. The Executive (Executive Report 1955, p. 64) noted that the union's objection to visits by foreign musicians had led to 'public controversy on many occasions', but said that it was inappropriate to comment on individual cases.

Generally, 1955 is cited as the year in which the ban was lifted; the Union's official history, for instance, notes that this marked the creation of a 'new deal allowing musical exchanges between Britain and the US' (Jempson 1993, p. 21). Interestingly, the tone of the internal documents from the MU archive are decidedly understated at this time and give little flavour of the significance of this move. The Executive's Report to the next conference (in 1957) after the first US-UK exchanges had taken place, merely noted that 'good relations continue to exist' with the AFM (Executive Report 1957, p. 52), that there had been a great deal of correspondence and that the General Secretary (Hardie Ratcliffe) had met Petrillo for informal discussions. It was further noted that:

In accordance with the policy decided upon by the Executive Committee, National Office officials approved an 'exchange' arrangement under which, between March and May 1956, Stan Kenton and his Orchestra performed in Britain and Ted Heath and his Orchestra performed in the USA. (Executive Report 1957, p. 54). ${ }^{9}$

Ten similar exchanges had subsequently been agreed. Thus the relaxation of restrictions on US dance bands in particular can be accurately dated to 1955, when the reciprocal exchange agreement was made to allow for tours in 1956 led by Heath and Kenton with the promoter/agent Harold Davison playing a key role in facilitating the exchanges (Francis n.d.).

In 1959 the Executive reported that dealings with the AFM had 'been much more frequent than formerly', and that a principle of 'approximate reciprocity' had been established (Executive Report 1959, pp. 73-4). The result was a number of ill-matched tours of the US with UK jazz bands often playing the same shows as US rock and rollers (McKay 2005, p. 122). Meanwhile an exchange scheme for orchestral musicians was not working to the Executive's satisfaction and it opined that 'the exchanges had been of no advantage to the profession, and that on some occasions they had been harmful' (Executive Report 1959, pp. 74-5). It had therefore tried, unsuccessfully, to limit such exchanges with the USA to three per annum. The Union had also been unsuccessfully pressing VOCA to design a quota system.

By 1961 contact with the AFM was said to be 'continuous owing to arrangements made, and requiring consultation with the Federation, for the reciprocal exchange of bands' (Executive Report 1961, p. 66). A similar report was filed in 1963. In 1965 it was reported that the 'British Invasion' of the USA had seen frequent contact with the AFM, especially on reciprocal exchanges (Executive Report 1965, p. 71). It was noted that 'nearly all those groups now visiting the U.S.A. from Britain constitute "beat" or "pop" groups' (Executive Report 1965, p. 76). In 1966 
the Union again received assurances from the Ministry that it would be consulted over permits and that none would be issued for dance band musicians without a favourable reference from the Union (LAB 8/3310).

In the following years the Union continued to debate reciprocal arrangements but following the victory of the Conservative Party in the 1979 general election, the government was increasingly unwilling to restrict tours by foreign musicians. The 1981 Conference heard that the Department of Employment was increasingly taking an 'unhelpful' attitude by too easily accepting arguments that imported foreign musicians were integral to touring shows when the union felt that UK musicians could easily do the work (Executive Report and Conference Agenda 1981, p. 55). The union's role was now 'advisory' rather than consultative - 'the sole function being to advise on the availability of resident labour' (Executive Report and Conference Agenda 1981, p. 55).

\section{Discussion}

The archives show that the MU's relationship with 'alien' musicians has always been complicated, especially during the period from the 1920s to the 1950s. Previous literature on this topic has included some confusion about the timing, scope and motivation of the restrictions ${ }^{10}$ and we have taken a first step towards clarifying some key issues. Importantly, any understanding of the MU's policies need consideration of the context it was working in and an appreciation of the key individuals - such as Batten - involved in creating and enforcing MU policy. Any targeted opposition from the MU to tours by US jazz musicians must also be located within in a broader context of MU opposition to all alien musicians regardless of nationality or genre. It is also important to note that there is a noticeable shift in rhetorical strategy from the MU away from outright opposition to all foreign performers and towards reciprocal exchanges.

Meanwhile many previous mentions of these historical events cast the MU as the villain of the piece. Oliver (1980, p. 80) says that 'the MU ban was as inflexibly applied as it was stupidly imposed' and Baily (1990, p. 169) refers to the 'blinkered' and 'stubborn' MU imposing a 'notorious ban'. However, arguments were and can still be made in favour of the union's actions. It is important to note that the MU was hardly alone in wishing to restrict entry by 'alien' workers. In addition many promoters seemingly accepted the need for restrictions. While the Ministry often disagreed with the MU's approach, it also accepted the principle of restriction. Even the VAF, which helped facilitate visits by international 'variety' acts, also came to accept restrictions (Honri 1997, p. 118). Furthermore, the MU's tactics were mirrored not only by the AFM but in places such as France (Honri 1997, p. 100) and Australia (Dreyfus 2009).

Perhaps the most forceful defence of the MU's actions comes from Harry Francis, its official charged with the responsibility for overseeing the union's reciprocal exchanges. He firmly supported the idea of reciprocal exchanges which, he says, the MU always supported in principle. Francis claims that by the 1960s reciprocity was so well established that its wisdom 'had fairly well dawned upon those who had first attacked it' (Francis n.d.). Even Jack Hylton, himself denied entry to the USA, saw the need for restrictions and wanted only musicians of 'exceptional quality' granted entry to the UK (LAB 2/1188/EDAR528/2/1929). 
What was at stake here was not so much whether certain nationalities were better musicians, but the extent to which access to a nationally defined labour market should be restricted.

While many previous accounts (such as Oliver and Baily above) refer to a 'ban', the reality is more nuanced than such a blanket description suggests. In fact, we found no instance of the MU using the word 'ban' in its internal documents to describe its policy. That discussion of the 'ban' has hitherto focused on US dance bands is due to several factors including the British bands being denied opportunities to perform in the USA, the exceptional character of American popular music, and the interests of subsequent historians. Most importantly, the notion of a 'MU ban' is somewhat misleading as only the Ministry had the power to implement such a veto, although it was clearly under pressure from the MU to do so.

The restrictions should also be located in the context of musicians' working lives. The entertainment industries are notoriously unstable places to work in and the MU has faced perennial problems in maintaining existing terms and conditions in workplaces such as music halls, cinemas and orchestras. It was under constant threat from new technology, non-union labour (especially military bands), economic downturn and unscrupulous employers. Under such circumstances a policy of protectionism had some logic.

Moreover, the MU's stance was based on the understandable idea that unions are strongest when they are able to control the supply of labour. Inevitably this means denying opportunities for some to work in order to maintain the jobs and terms and conditions of those already in work. The result may not always be palatable, but the action is not illogical. If there are limited opportunities to work, then limiting access to the labour market in order to maintain wages and working conditions makes some sense. However, the MU remained stubbornly resistant to any notion that work opportunities might expand to the benefit of all. Here it is important to note that restrictions on foreign performers were born in hard economic times and eased during the postwar economic boom as more work opportunities became available. In reality it was capitalist cycles of boom and slump which polarised opinion. The MU was right to see capitalism as the problem, but wrong to allow its concerns to be articulated in xenophobic ways.

The factors outlined above do not excuse some of the MU's official stances, but do suggest more complex motives than a simple desire to ban foreigners. That said, unfortunately aspects of the restrictions had clear racist overtones. These had earlier precedents. In the jingoistic atmosphere which followed the 1914-1918 war, Fort Greenwood (then acting as the MU London Branch Joint Secretary with Batten) wrote to the Sunday Times about a proposed tour by the Viennese Opera Company, saying it was a 'monstrous thing' for agents to suggest that audiences wanted to hear opera in German (London Meeting Agenda, 22 February 1924). Rye (1990) notes that the great demand for 'African' jazz bands in the early 1920s sparked accusations that such acts were immoral and undesirable. Certainly Ministry archives show that racism was prevalent elsewhere and restrictions on 'aliens' were widely supported within the entertainment industries. The Actors Association wrote to the Ministry in December 1922, complaining that following appearances by a black troupe entitled the Coloured Society:

Unfortunately, a large number of these negroes did not leave the Country, but settled down, chiefly in London ... and it is a well known scandal in theatrical circles that most of these 
people who stayed behind have lived with white women and are responsible for a great number of evils of this kind. (Lab 2 1187/EDAR3011/1922/AMENDED)

In 1925 the US agent William Morris, who was working with the UK-based Fosters Agency, was quoted as saying: 'I strongly object to coloured artists being employed where food is served to white people' (Daily Express, 14 October 1925, in AR278/41/ 1925-A19 1926).

Given that xenophobia and overt racism have long been part of UK life (Winder 2004) it would be surprising if the MU was not contaminated with such views. Certainly some of Batten's writings discussed earlier in this article raise suspicions about his motives. Indeed, the MU's own official history recognised that inevitably xenophobic, racist and anti-Semitic sentiments have at times accompanied its longest running campaign to restrict the over-use of foreign musicians' (Jempson 1993, p. 50). In fairness it should also be noted that jingoistic sentiments were far from universal within the MU and the minutes of the London Meeting of 13 September 1938, for instance, express concern about the anti-Semitic tone adopted by Melody Maker's editor, P. Mathieson Brooks, in an article about 'the alien menace', and called for the union to write a letter of complaint. ${ }^{11}$ However, the spectre of racism still hangs over the MU's treatment of 'alien' musicians. McKay (2005, p. 122) argues that the restrictions did 'sterling work over two decades in keeping professional British jazz and dance music white' and asks if racism lay behind the MU's policy, referring to an account of an MU official complaining about 'American negro bands' coming in to play music which British musicians could have played (McKay 2005, p. 146). He continues that the ban:

meant that for two crucial decades that saw every stylistic and technical development in jazz from Armstrong to Miles (Davis), virtually every one of the music's practitioners, nearly all of whom were black, was kept out of Britain by an overwhelmingly white organization, the Musicians' Union. (McKay 2005, p. 147)

McKay (2005) says that while the ban was retaliatory, it effectively acted as a 'colour bar'. However, McKay (citing Oliver 1990, p. 14) also notes that one effect of the restrictions was to increase the demand for resident black musicians, and that the ban applied equally to white and black musicians.

Three additional criticisms of the MU's actions should be made. First, the restrictions prohibited the exchange of musical ideas between countries which might have helped British musicians learn from - and compete with - the standards of American jazz. Second, the logic of the MU's arguments hinged in part on the idea of a fixed demand for musical labour combined with the existence of a closed-shop labour force, and there is scant evidence that either existed. In fact, as Nott (2002, pp. 143-5) has demonstrated, the MU systemically failed to recruit members of the dance band profession. This partly reflected a refusal to acknowledge how musical labour differed from other kinds of labour, especially the high overlap between amateurs and professionals within the music market. Third, the MU's focus on enforcing restrictions rather than arranging reciprocal exchanges meant that British musicians (including its members) lost out on growing their international audiences. It is salutary that the 'British Invasion' of the USA from 1964 to 1966 happened only after restrictions against foreign performers eased on both sides of the Atlantic. Subsequently the British music economy and its culture benefited enormously from reciprocal agreements which ultimately enabled British musicians to tour the 
US and elsewhere. While the relaxation of restrictions and adoption of reciprocal exchanges may not have caused the 'Invasion', British bands certainly could not have made anywhere near the same international impact had the restrictions remained in place.

Even though popular music scholars have tended to view the ban as detrimental to British musical life, the consequences of the MU's policies towards foreign musicians were complicated. It is also difficult to know for certain whether British musicians would have had more or fewer opportunities for both musical development and paid work had there been no restrictions on foreign performers whatsoever. The genuine problems of working musicians in the UK and elsewhere are often too easily dismissed, and the history of the Musicians' Union as a whole has so far been under-researched.

The issue of work permit restrictions for foreign musicians remain a controversial and important part of the history of British music. As our opening quote shows, they remain a controversial issue. We can only hope that a better understanding of current international relationships in the global live music sector might emerge through a consideration of the complex relationships which underlay the MU's past actions.

\section{Endnotes}

1. For differing accounts of the start and end dates of the ban and its scope compare, for instance, Fordham (1995, pp. 20, 83), Godbolt (1984, pp. 116-18; 1989, pp. 28, 166), Green (1990, p. 40), McKay (2005, p. 30), Nott (2002, p. 146), Oliver (1990, p. 14, 80) and Rye (1990, p. 55).

2. Ministry records show that under CMD.318: No condition other than a limitation of the period of stay in this country is in general imposed in the case of concert instrumentalists and persons giving stage performances at music halls' (LAB 2/1188/EDAR528/1929). Examples of musicians who entered under this provision include Frank Sinatra, Nat 'King' Cole, The Ink Spots, Ella Fitzgerald, Duke Ellington, Big Bill Broonzy, Fats Waller, Art Tatum and Coleman Hawkins. See McKay (2005, p. 30), Melody Maker (19 June 1948, p. 1), Oliver (1990, p. 118), Rye (1990, p. 56) and Schwartz (2007, p. 39).

3. It became the Ministry of Labour and National Service in 1939, reverting back to its former title in 1959.

4. In 1923 the MU said that 2,000 of its members were unemployed (Parsonage 2005, p. 180).

5. This is verified in file AR78/41/1925-A9 1926.

6. Including Graham White (Liberal, Birkenhead East) on 31 July and Sir Gerald Hurst (Conservative, Moss Side) on 31 October.

7. The MU was accused of being slow to organise cinema musicians (Agenda for London Meeting, 25 May 1929).

8. See http://libguides.stir.ac.uk/content.php?pid= $337208 \&$ sid $=2791968$.

9. For more details see Francis (n.d.).

10. See Note 1, above.

11. It is also important to note that the MU has undertaken commendable anti-racist work elsewhere, including implementing a boycott of apartheid South Africa.

\section{References}

Baily, J. 1990. 'Qawwäli in Bradford: traditional music in a Muslim community', in Black Music in Britain, ed. P. Oliver (Buckingham, Open University Press), pp. 153-65

Cessarani, D. 1996. 'Citizenship and nationality in Britain', in Citizenship, Nationality and Migration, ed. D. Cessarani and M. Fullbrook (London, Routledge), pp. 57-73

Clayton, G. 2006. Textbook on Immigration and Asylum Law (Oxford, Oxford University Press)

Dreyfus, K. 2009. 'The foreigner, the Musicians' Union and the State in 1920's Australia: a nexus of conflict', Music and Politics, 3, pp. 1-17

Dummett, A., and Nicol, A. 1990. Subjects, Citizens, Aliens and Others: Nationality and Immigration Law (London, Weidenfeld and Nicolson)

Fifield, C. 2005. Ibbs and Tillett: The Rise and Fall of a Music Empire (Aldershot, Ashgate)

Fordham, J. 1995. Jazz Man: The Amazing Story of Ronnie Scott and His Club (London, Kyle Cathie) 
Francis, H. n.d. The History of British Jazz. http://www.jazzprofessional.com/Francis/Francis_Jazz\%20development.htm (accessed 1 August 2011)

Godbolt, J. 1984. A History of Jazz in Britain 1919-1950 (London, Quartet)

Godbolt, J. 1989. A History of Jazz in Britain 1950-1970 (London, Quartet)

Green, J. 1990. 'Afro-American symphony: popular black concert hall performers 1900-40', in Black Music in Britain, ed. P. Oliver (Buckingham, Open University Press), pp. 34-44

Holmes, C. 1991. A Tolerant Country? Immigrants, Refugees and Minorities in Britain (London, Faber \& Faber)

Honri, P. 1997. Music Hall Warriors: A History of the Variety Artistes Federation (London, Greenwich Exchange)

Hubbard, P. 1985. 'Synchronized sound and movie-house musicians, 1926-29', American Music, 3, pp. 429-41 Jempson, M. 1993. The Musicians' Union 1893-1993: A Centenary Celebration (London, Musicians' Union)

Kraft, J. 1994a. 'Musicians in Hollywood: work and technological change in entertainment industries, 19261940', Technology and Culture, 35, pp. 289-314

Kraft, J. 1994b. 'The "Pit" musicians: mechanization in the movie theaters, 1926-1934', Labor History, 35, pp. 66-89

McKay, G. 2005. Circular Breathing (London, Duke University Press)

Mermey, M. 1929. 'The vanishing fiddler', North American Review, 227, pp. 301-7

Moore, J. 2006a. 'Paul Specht'. The British Dance Band Encyclopaedia. http://www.mgthomas.co.uk/Dancebands/ American\%20Visitors/Pages/Paul\%20Specht.htm (accessed 15 February 2012)

Moore, J. 2006b. 'The sensitive matter of work permits'. The British Dance Band Encyclopaedia. http://www. mgthomas.co.uk/dancebands/American\%20Visitors/Pages/Work\%20Permits.htm (accessed 15 February 2012)

Nott, J. 2002. Music for the People: Popular Music and Dance in Interwar Britain (Oxford, Oxford University Press)

Oliver P. (ed.) 1990. Black Music in Britain (Buckingham, Open University Press)

Parsonage, C. 2005. The Evolution of Jazz in Britain 1880-1935 (Aldershot, Ashgate)

Rye, H. 1990. 'Fearsome means of discord: early encounters with black jazz', in Black Music in Britain, ed. P. Oliver (Buckingham, Open University Press), pp. 45-57

Schwartz, R. 2007. How Britain Got The Blues: The Transmission and Reception of American Blues Style in the United Kingdom (Aldershot, Ashgate).

Smith, A. 2009. 'Contemporary dancers and orchestral musicians in line for visa concession', The Stage, 5 May. http://www.thestage.co.uk/news/2009/05/contemporary-dancers-and-orchestral-musicians-in-line-forvisa-concessions/

Winder, R. 2004. Bloody Foreigners (London, Abacus) 